\title{
Pendampingan Penerapan Strategi Promosi Berbasis Digital Bagi UMKM Di Wilayah Kota Bogor
}

\author{
Budi Setiawan ${ }^{1}$ dan Adil Fadillah ${ }^{2}$ \\ ${ }^{1}$ Program Studi Manajemen, Institut Bisnis dan Informatika Kesatuan \\ Bogor, Indonesia \\ ${ }^{2}$ Program Studi Manajemen Pemasaran, Institut Bisnis dan Informatika Kesatuan \\ Bogor, Indonesia
}

E-Mail: budi.setiawan@ibik.ac.id
Submitted: APRIL 2020

Accepted: MEI 2020

\begin{abstract}
ABSTRAK
Operasionalisasi bisnis sangat membutuhkan adanya kreativitas yang tinggi dan adaptif terhadap perubahan. Kreativitas dalam bisnis dengan memanfaatkan perkembangan teknologi informasi, telah banyak mengubah cara pandang pebisnis dalam menjalankan bisnisnya. Tidak hanya pebisnis berskala besar, sektor UMKM pun dapat memanfaatkan hal ini untuk pemasaran bisnisnya. UMKM di Kota Bogor harus memiliki kemampuan dan keterampilan terkait kreativitas bisnis. Dengan ini, Dinas Koperasi dan UMKM Kota Bogor bekerjasama dengan STIE Kesatuan menyelenggarakan Pelatihan Peningkatan Kreativitas UMKM dalam Pemasaran di Dunia Digital bagi UMKM di Kota Bogor, yang berlokasi di Hotel Grand Asana Pangrango Bogor. Kegiatan pelatihan ini bertujuan untuk meningkatkan keterampilan pelaku UMKM dalam memanfaatkan internet bagi operasional bisnis. Dengan ini, diharapkan terbentuknya pengetahuan dan pemahaman UMKM Kota Bogor akan keberadaan dan perkembangan teknologi informasi, bagi optimalisasi bisnis serta Tercapainya optimalisasi pengetahuan identifikasi survey pasar berbasis digital, dalam upaya meningkatkan kinerja bisnis UMKM Kota Bogor
\end{abstract}

Kata Kunci : UMKM, Pemasaran digital, Kreativitas bisnis

\section{PENDAHULUAN}

Operasionalisasi bisnis sangat membutuhkan adanya kreativitas yang tinggi dan adaptif terhadap perubahan. Dinamika kompetisi bisnis yang semakin kompleks menjadikan kreativitas adalah hal yang harus dapat dilakukan oleh para pelaku bisnis. Kreativitas pada prinsipnya adalah kemampuan menciptakan hal baru dari yang sebelumnya sudah ada. Baru di sini dalam arti fungsi baru, tampilan baru, maupun manfaat tambahan baru. Bisnis tanpa adanya kreativitas nampaknya hanya menunggu waktu saja untuk kemudian tergilas roda perubahan zaman, untuk kemudian tergantikan dengan para pebisnis lain. Apalagi di era kecanggihan teknologi informasi saat ini, Dinamika bisnis yang terjadi, didukung atau dibentuk oleh beragam faktor yang saling berkaitan satu sama lainnya. Perkembangan teknologi informasi menjadikan pebisnis harus adaptif dan jeli melihat beragam peluang dan memanfaatkan peluang yang ada.

Kreativitas dalam bisnis dengan memanfaatkan perkembangan teknologi informasi, telah banyak mengubah cara pandang pebisnis dalam menjalankan bisnisnya. Kreativitas artinya melihat dengan sudut pandang yang baru, seringkali bahkan dari sudut pandang yang tidak umum atau di luar kebiasaan. Keberadaan media sosial yang semakin gencar misalnya, turut memantik kreativitas dalam berpromosi menawarkan produk ke pasar sasaran. Tidak hanya pebisnis berskala besar, sektor UMKM pun dapat memanfaatkan hal ini untuk pemasaran bisnisnya.

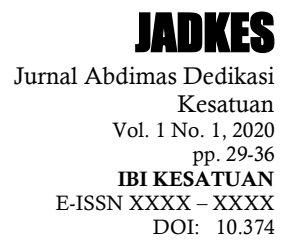


Pendampingn

Promosi Produk

$U M K M$

30

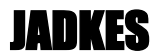

Jurnal Abdimas Dedikasi

Kesatuan

Vol. 1 No. 1, 2020

pp. $29-36$

IBI KESATUAN

E-ISSN XXXX - XXXX

DOI:
Peran usaha mikro kecil dan menengah (UMKM) dalam memberi kontribusi aktif dalam perekonomian tidak diragukan lagi, termasuk pada UMKM di wilayah Kota Bogor. Meski kontribusinya signifikan dalam perekonomian, bukan berarti keberadaan UMKM di Kota Bogor tidak mengalami berbagai tantangan bisnis. Dalam eksistensinya, terdapat banyak tantangan bisnis yang membuat tidak sedikit dari UMKM yang ada kemudian menutup usaha, atau setidaknya mengalami penurunan omset usaha. Kondisi inilah yang harus diwaspadai dengan sungguh- sungguh oleh para UMKM di Kota Bogor, agar tidak mudah goyah ketika ditempa beragam tantangan bisnis. Salah satunya adalah dengan memanfaatkan keberadaan teknologi dan informasi yang ada. UMKM Kota Bogor perlu memanfaatkan dengan baik akan keberadaan teknologi informasi, agar berimbas pada benefit usaha.

Bisnis di dunia digital menuntut kemampuan pebisnis untuk dapat beradaptasi, di mana dalam aktivitasnya didukung dan difasilitasi oleh kemajuan perkembangan teknologi dan informasi. Saat ini, suatu produk (barang maupun jasa) yang ditawarkan oleh produsen, akan sangat mudah ditemukan oleh konsumen, selama dapat diakses melalui internet. Ketersediaan beragam gawai (gadget) saat ini sudah dilengkapi dengan kemampuan akses internet, di mana kemampuannya semakin meningkat dari waktu ke waktu. Akses internet menjadi semakin memadai dilakukan di mana saja, kapan saja dan oleh siapa saja. Dengan demikian sangat terbuka peluang bagi UMKM untuk dapat menjalankan bisnisnya dengan baik, dan bahkan meningkatkan kinerja bisnisnya melalui pemasaran digital.

UMKM di Kota Bogor harus memiliki kemampuan dan keterampilan terkait kreativitas bisnis. Dilansir dari perizinan.kotabogor.go.id, Kepala Dinas Koperasi, Usaha Mikro, Kecil dan Menengah (UMKM) Kota Bogor, Anas S. Rasmana mengatakan berdasarkan hasil survei yang dilakukan Dinas Koperasi dan UMKM Kota Bogor, UKM di Kota Hujan memberikan kontribusi sebesar 67 persen terhadap Produk Domestik Bruto (PDB). Kontribusi yang terjadi disebabkan karena tidak banyaknya pabrik-pabrik di Kota Bogor. Sehingga muncul usaha mikro, kecil dan menengah baru yang dalam 15 tahun belakangan tercatat ada 15 hotel baru, 280 restoran baru, 5 rumah sakit baru, perkantoran baru dan di bidang jasa lainnya. Mengacu pada hal tersebut di atas maka sangat penting bagi para UMKM di Kota Bogor untuk senantiasa secara berkesinambungan, mendapatkan pelatihan yang tepat. Pelatihan dimaksud adalah bagaimana caranya UMKM dapat berpikir dan bertindak secara kreatif, dan memiliki kemampuan dalam mengatasi berbagai hambatan yang ada.

Sebagai salah satu perguruan tinggi swasta terkemuka di Indonesia yang berdomisili di Kota Bogor, Sekolah Tinggi Ilmu Ekonomi (STIE) Kesatuan senantiasa berusaha berpartisipasi aktif dalam peningkatan perekonomian masyarakat. Para dosen tetap yang berada dalam homebase STIE Kesatuan pada khususnya, senantiasa berupaya sekuat tenaga dalam menjalankan tridharma yang menjadi kewajibannya. Seluruh civitas akademik bersatu padu dalam berkontribusi positif. Dalam aspek pengabdian pada masyarakat, para dosen di STIE Kesatuan dengan bekal keahlian dan keilmuan yang dimiliki, senantiasa berupaya dapat memberi manfaat kepada masyarakat.

Strategi promosi pemasaran bisnis UMKM di Kota Bogor dengan memanfaatkan keberadaan media sosial, dapat menjadi salah satu fokus pengabdian pada masyarakat. Para dosen di STIE Kesatuan memiliki sejumlah keahlian yang dapat diterapkan pada UMKM di Kota Bogor, agar dapat bermanfaat dalam meningkatkan eksistensi bisnisnya saat ini. Salah satu hal penting adalah bagaimana caranya memanfaatkan keberadaan teknologi informasi yang ada, untuk mengoptimalkan kinerja bisnisnya. Pemasaran bisnis melalui platform digital saat ini semakin berkembang pesat. Hal ini sebagaimana terindikasi dari keberadaan beragam situs jual beli online dan tentu saja media sosial yang semakin bertambah dan berkembang.

Keberadaan media sosial pun semakin berkembang dengan pesat, setidaknya ada platform media sosial yang sangat memungkinkan untuk dapat digunakan dalam berbisnis. Keberadaan beragam platform seperti Facebook, Instagram misalnya, selain digunakan sebagai media dalam berinteraksi melalui dunia maya, juga dapat digunakan 
dalam mempromosikan keberadaan produknya secara luas. Dengan demikian diperlukan sebuah kreativitas, sehingga bisnis yang berjalan saat ini benar-benar dapat dioptimalkan dengan memanfaatkan keberadaan internet, atau berbasis digital.

Tujuan pengabdian pada masyarakat dengan penyelenggaraan pelatihan Strategu promosi berbasis digital bagi UMKM di wilayah Kota Bogor, yakni sebagaimana disampaikan berikut ini:

1. Memberikan pengetahuan dan pemahaman mengenai keberadaan dan potensi media sosial dalam mempromosikan produk bisnis.

2. Memberikan pengetahuan dan pemahaman bagi UMKM dalam merancang promosi produk di media sosial.

3. Memberikan pengetahuan cara meraih pelanggan melalui teknik content marketing yang menarik dan tepat sasaran.

Kegiatan pengabdian pada masyarakat ini diharapkan memiliki manfaat kegiatan yang tepat sasaran dan berdampak luas bagi peningkatan bisnis UMKM di Kota Bogor. Pelaksanaan kegiatan secara terstruktur diharapkan dapat mengoptimalkan capaian yang ditargetkan. Pelatihan Peningkatan Kreativitas UMKM dalam Pemasaran di Dunia Digital bagi UMKM di Kota Bogor yang diselenggarakan oleh Dinas Koperasi dan UMKM Kota Bogor bekerjasama dengan STIE Kesatuan, bertujuan untuk meningkatkan keterampilan pelaku UMKM dalam memanfaatkan internet bagi operasional bisnis. Manfaat penyelenggaraan kegiatan pelatihan ini bagi para pelaku UMKM adalah di Kota Bogor, adalah sebagai berikut:

1. Terciptanya UMKM Kota Bogor yang memiliki pengetahuan dan pemahaman mengenai pentingnya identifikasi potensi dalam berbisnis.

2. Terbentuknya pengetahuan dan pemahaman UMKM Kota Bogor akan keberadaan dan perkembangan teknologi informasi, bagi optimalisasi bisnis.

3. Tercapainya optimalisasi pengetahuan identifikasi survey pasar berbasis digital, dalam upaya meningkatkan kinerja bisnis UMKM Kota Bogor

Hidayat, A. R., \& Kumadji, S. (2016) menjelaskan bahwa dunia pemasaran telah memasuki era baru yang revolusioner. Saat efektivitas komunikasi pemasaran tradisional mengalami penurunan, sebuah metode baru di dunia pemasaran mengalami perkembangan signifikan. Cara baru tersebut dikenal sebagai "pemasaran digital" yang menggabungkan faktor-faktor psikologis, humanis, antropologis, dan teknologis melalui multimedia dengan kapasitas besar dan interaktif. Hasilnya adalah babak baru interaksi antara produsen, intermediari pasar, dan konsumen, dengan perantaraan medium teknologi bergerak (mobile) sebagai unsur dominan.

Munculnya internet di Indonesia, dengan "pasar" yang begitu besar, tentu menjadi salah satu faktor yang menyebabkan munculnya model periklanan yang baru, yaitu dengan menggunakan internet atau secara online, atau biasa disebut dengan pemasaran digital (digital marketing). Digital marketing adalah sebuah strategi pemasaran yang memanfaatkan medium digital, bisa melalui website, telepon genggam, e-mail, blog, viral dan lainnya (Wertime, 2008:30). Berkembangnya digital marketing, memunculkan lagi satu jenis pemasaran melalui telepon genggam atau yang biasa disebut dengan mobile advertising. Mobile advertising adalah model baru dari periklanan dimana menggunakan media telepon seluler untuk beriklan.

Menurut Joseph (2011: 32) dalam Tan, A. M., Lestari, M. T., \& Ali, D. S. F. (2016), digital marketing merupakan suatu keadaan dimana pemasar harus menguasai tiga hal dari konsumen yaitu pikiran, hati dan semangat mengacu kepada pemasaran yang bersifat elektronik berbasis internet. Memacu pemasaran untuk menciptakan produk yang selain memberikan kualitas dan pelayanan juga memberikan pengalaman yang lebih kepada konsumen.

Komunikasi pemasaran (Kennedy dan Soemanagara, 2009: 5) dapat dinyatakan sebagai kegiatan komunikasi yang bertujuan untuk menyampaikan pesan pada konsumen dengan menggunakan berbagai media, dengan harapan agar komunikasi dapat menghasilkan perubahan pengetahuan, perubahan sikap, dan perubahan tindakan
Pendampingan

Promosi Produk

UMKM

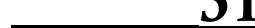


Pendampingn Promosi Produk $U M K M$

$\underline{32}$

\section{JADKES}

Jurnal Abdimas Dedikasi Kesatuan

Kesatuan
Vol. 1 No. 1, 2020

pp. 29-36

pp. 29-36

IBI KESATUAN
E-ISSN XXXX - XXXX

DOI: yang dikehendaki. Sehingga dapat disimpulkan bahwa strategi komunikasi pemasaran digital adalah suatu kegiatan promosi merek yang sudah direncanakan dan disusun secara sistematis serta membangun interaksi merek dengan penggunaanya melalui aktivitas hiburan, kebudayaan, sosial atau aktivitas publik yang menarik perhatian lainnya menggunakan media baru atau digital pemasaran yang saat ini menjadi bagian penting dalam mencapai target konsumen.

\section{PELAKSANAAN KEGIATAN \\ Waktu Pelaksanaan}

Kegiatan Pelatihan Peningkatan Kreativitas UMKM dalam Pemasaran di Dunia Digital bagi UMKM di Kota Bogor, diselenggarakan atas kerjasama antara LPPM STIE Kesatuan dengan Dinas Koperasi dan UMKM Kota Bogor selama 2 hari pada tanggal 20 - 22 Februari 2019. Tempat penyelenggaraan di Hotel Asana Grand Pangrango Bogor.

\section{Kerangka Pemecahan Masalah}

Permasalahan yang diangkat dalam kegiatan pengabdian pada masyarakat adalah meningkatkan pengetahuan, pemahaman mengenai pemasaran dalam rangka meningkatkan kinerja UMKM. Kerangka pemecahan masalah dimaksud dilakukan dengan menerapkan langkah kerja dalam pengabdian pada masyarakat sebagai berikut:

1. Membuat materi pelatihan dalam bentuk slide powerpoint yang atraktif, dinamis, sederhana, dan mampu menarik perhatian para peserta pelatihan, sesuai dengan tema yang diberikan.

2. Melaksanakan kegiatan dengan pemberian materi pelatihan dengan mengkombinasikan berbagai metode terpadu, yakni diskusi dua arah, tanya jawab, dan permainan interaktif. Hal ini agar kegiatan dapat berjalan antusias, peserta tidak mudah merasa bosan mengikutinya.

3. Memberikan tambahan wawasan mengenai peningkatan kreativitas bisnis, dengan memperhatikan dinamika pasar yang terus berkembang dan kemajuan teknologi informasi (internet).

Adapun kerangka pikir untuk pemecahan masalah dapat dijelaskan dalam bentuk matrik sebagai berikut:

Tabel 1. Masalah dan Solusi Yang Ditawarkan

\begin{tabular}{|c|c|c|}
\hline & Masalah & Upaya Pemecahan Masalah \\
\hline 1 & $\begin{array}{l}\text { Bagaimana memberikan } \\
\text { pengetahuan dan pemahaman } \\
\text { UKM mengenai identifikasi } \\
\text { media sosial bagi promosi } \\
\text { pemasaran produk bisnis. }\end{array}$ & $\begin{array}{l}\text { Upaya yang kemudian dilakukan untuk } \\
\text { menyelesaikan masalah tersebut adalah melalui } \\
\text { ceramah, tanya jawab, diskusi dan contoh kasus, } \\
\text { dalam melakukan identifikasi media sosial bagi } \\
\text { promosi produk. }\end{array}$ \\
\hline 2 & $\begin{array}{l}\text { Bagaimana memberikan } \\
\text { pemahaman mengenai } \\
\text { karakteristik pemasaran digital } \\
\text { berdasarkan platform dan } \\
\text { karakteristik khasnya. }\end{array}$ & $\begin{array}{l}\text { Dilakukan dengan cara memberikan ceramah, tanya } \\
\text { jawab, diskusi dan menjelaskan contoh, praktek } \\
\text { langsung pemasaran digital melalui media sosial }\end{array}$ \\
\hline 3 & $\begin{array}{l}\text { Bagaimana pemahaman } \\
\text { mengenai pentingnya } \\
\text { mempraktekkan promosi } \\
\text { pemasaran bisnis dengan } \\
\text { menggunakan media sosia. }\end{array}$ & $\begin{array}{l}\text { Dilakukan dengan cara memberikan ceramah, tanya } \\
\text { jawab, dan diskusi yang terkait dengan praktek } \\
\text { membuat content digital yang menarik }\end{array}$ \\
\hline
\end{tabular}

\section{Khalayak Sasaran Antara Yang Strategis}

Sasaran kegiatan ini adalah pelaku UMKM di wilayah Bogor, yang menjadi binaan strategis dari Dinas Koperasi dan UMKM Kota Bogor. Pertimbangan prinsipil dalam melakukan penetapan sasaran pelatihan ini adalah untuk meningkatkan kemampuan pelaku UMKM dalam mengelola usaha khususnya peningkatan kreativitas UMKM dalam pemasaran di dunia digital bagi UMKM di Kota Bogor. Media sosial sebagai 
salah satu platform di mana orang dapat berinteraksi satu sama lain melalui internet, menjadikan terbukanya peluang besar dalam mempromosikan produk bisnis.

Hal ini akan memiliki dampak yang luas di berbagai bidang kinerja bisnis UMKM, khususnya tentu saja berdampak pada peningkatkan kinerja keuangan UMKM. Pertimbangan selanjutnya adalah bahwa STIE Kesatuan sebagai Perguruan Tinggi swasta terkemuka di Indonesia, memiliki fungsi pengabdian kepada Masyarakat melalui bidang keilmuan pemasaran memiliki kewajiban untuk mengimplementasikan bidang keilmuannya dalam membantu pelaku UMKM. Bentuk bantuan profesional yang diberikan ini, diharapkan mampu meningkatkan keterampilan UMKM di Kota Bogor, dalam menggunakan dan memanfaatkan teknologi informasi, melalui promosi dengan memanfaatkan ketersediaan media sosial.

\section{Keterikatan}

Kegiatan pengabdian pada masyarakat peningkatan kompetensi UMKM Kota Bogor melalui strategi promosi berbasis digital ini diselenggarakan oleh STIE Kesatuan yang secara teknis dilakukan oleh Lembaga Penelitian dan Pengbdian kepada Masyarakat (LPPM) dengan dukungan sumber daya manusia yang memiliki latar belakang keilmuan di bidang pemasaran. Hal-hal yang berkaitan dengan sumber daya manusia serta sarana dan prasarana LPPM STIE Kesatuan dapat dijelaskan sebagai berikut :

a. Memiliki dosen dengan kompetensi keilmuan yang handal, profesional, berintegritas dan berpengalaman dalam menghasilkan berbagai jenis karya tulis ilmiah yang bermutu. Hasil penelitian dosen dipublikasikan pada jurnal internasional bereputasi, jurnal nasional terakreditasi Dikti, dan jurnal nasional ber-ISSN.

b. Memiliki dosen yang profesional dan berpengalaman dalam pelaksanaan kegiatan penataran dan pelatihan, di berbagai bidang, baik pemasaran maupun bidang-bidang bisnis lainnya yang relevan.

Adapun potensi strategis yang dapat dimiliki oleh pelaku UMKM di Kota Bogor pada khususnya adalah keinginan yang kuat untuk meningkatkan kemampuan dalam pemasaran digital yang diharapkan dapat membantu dalam meningkatkan kinerja bisnis UMKM. Hal ini tentu saja merupakan capaian strategis yang menjadi fokus utama dari kegiatan.

\section{METODE KEGIATAN}

Metode kegiatan ini diimplementasikan berupa Pelatihan STRATEGI PROMOSI BERBASIS DIGITAL BAGI UMKM DI WILAYAH KOTA BOGOR. Setelah selesai kegiatan pelatihan dilakukan, sangat diharapkan para pelaku UMKM di Kota Bogor pada khususnya, mampu mengimplementasikan pengetahuan dan pemahaman yang telah diperoleh untuk mengoptimalkan keberadaan bisnisnya. UMKM menjadi memiliki kemampuan memadai untuk memanfaatkan keberadaan media sosial untuk mempromosikan produknya. Berikut disajikan tahapan pelatihan yang dilakukan:

\section{Tahap Persiapan}

Pada tahap persiapan kegiatan, maka dilakukan beberapa kegiatan yang meliputi beberapa hal berikut:

a. Observasi, pemetaan dan identifikasi calon peserta, bagaiamana latar belakang bisnis mereka, skala bisnisnya, dan berbagai hal relevan lainnya.

b. Pemantapan dan penentuan lokasi dan sasaran, sesuai dengan yang telah ditetapkan oleh dinas

c. Penyusunan bahan/materi pelatihan: slide presentasi dan berbagai video pendukung yang relevan, untuk kegiatan pelatihan promosi melalui media sosial bagi UMKM.
Pendampingan

Promosi Produk

$U M K M$

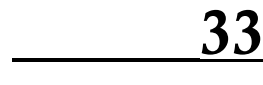


Pendampingn

Promosi Produk

$U M K M$

34

\section{JADKES}

Jurnal Abdimas Dedikasi Kesatuan

Vol. 1 No. 1, 2020

pp. 29-36

IBI KESATUAN

E-ISSN XXXX - XXXX

DOI:

\section{Tahap Pelaksanaan Pelatihan}

Tahap pelaksanaan pelatihan ini merupakan tahapan inti penyelenggaraan kegiatan pelatihan kreativitas promosi produk, dengan memanfaatkan media sosial. Pada tahap ini kegiatan yang dilakukan sebanyak 3 sesi yang dilaksankan secara proporsional, yakni sebagai berikut:

Sesi pertama. Pada sesi ini pembicara memberikan pengetahuan dan pemahaman mengenai pentingnya mengenal keberadaan media sosial, karakteristik media sosial, dan gambaran penggunanya.

Sesi kedua. Pada sessi ini pembicara menjelaskan gambaran singkat mengenai potensi media sosial dalam mengembangkan bisnis. Hal-hal yang dijelaskan meliputi:

1. Penetapan judul dan isi tulisan di sosial media yang menarik perhatian pengguna sosial media, dengan menggunakan teknik copy-writing dan pembuatan content berbasis gambar

2. Tips dan trik mendapatkan perhatian dari pengguna media sosial akan konten postingan yang mempromosikan produk usaha

3. Memanfaatkan fitur analisis Google yang tersedia secara gratis untuk dapat mengetahui trend pencarian.

\section{Metode Pelatihan}

Metode kegiatan pelatihan analisa data penelitian dapat dijelaskan sebagai berikut:

1. Metode Ceramah

Metode ini digunakan untuk memberikan penjelasan tentang pemahaman dasar akan digital marketing, social media marketing, membidik segmen pelanggan yang sesuai dengan produk bisnis, dan tips membuat konten yang tepat

2. Metode Tanya Jawab

Metode ini digunakan untuk mengetahui hal-hal yang belum dipahami secara baik oleh UMKM peserta, terkait strategi promosi pemasaran melalui platform digital.. Metode ini berupaya untuk mengeksplorasi materi yang disajikan agar dapat dipahami dengan baik oleh peserta. UMKM diberi kesempatan untuk bertanya konten yang tepat dan sesuai dengan produk bisnis yang dijalankan.

3. Metode Studi Kasus

Metode ini digunakan untuk mengajak peserta terlibat langsung dalam penulisan konten bisnis yang menarik di media sosial dan merancang strategi promosi yang tepat. Metode ini berupaya untuk mengaplikasikan materi yang disajikan agar dapat dipraktekkan oleh peserta dalam menjalankan usaha.

UMKM diminta untuk menetapkan target audience dari segmentasi yang sesuai dengan produk bisnisnya. Beragam faktor demografi kemudian digali dan diselaraskan dengan produk bisnis yang ditawarkan atau dijalani oleh UMKM.

\section{HASIL DAN PEMBAHASAN \\ Hasil}

Program kegiatan pengabdian kepada masyarakat ini dilaksanakan bagi pelaku UMKM di wilayah Bogor berupa pelatihan "STRATEGI PROMOSI BERBASIS DIGITAL BAGI UMKM DI WILAYAH KOTA BOGOR" yang dilaksanakan pada tanggal 20 - 22 Februari 2019 di Hotel Asana Grand Pangrango Bogor. Kegiatan pelatihan ini dilaksanakan dengan metode :

1. Metode Ceramah. Metode ini digunakan untuk memberikan penjelasan tentang pemahaman dasar akan digital marketing, social media marketing, membidik segmen pelanggan yang sesuai dengan produk bisnis, dan tips membuat konten yang tepat. Identifikasi dimulai dari karakteristik khas dari setiap platform media sosial. UMKM diberikan informasi akan kekuatan dan potensi yang dapat dioptimalkan dari setiap platform media sosial. Selain itu, UMKM diberikan pengetahuan akan optimalisasi media sosial dalam mempromosikan produk bisnis, sesuai target.

2. Metode Tanya Jawab. Metode ini digunakan untuk mengetahui hal-hal yang belum dipahami secara baik oleh UMKM sangat antusias mengajukan beragam. UMKM 
peserta, terkait strategi promosi pemasaran melalui platform digital. Metode ini berupaya untuk mengeksplorasi materi yang disajikan agar dapat dipahami dengan baik oleh peserta. UMKM diberi kesempatan untuk bertanya konten yang tepat dan sesuai dengan produk bisnis yang dijalankan.

3. Metode Studi Kasus. Metode ini digunakan untuk mengajak peserta terlibat langsung dalam penulisan konten bisnis yang menarik di media sosial dan merancang strategi promosi yang tepat. Metode ini berupaya untuk mengaplikasikan materi yang disajikan agar dapat dipraktekkan oleh peserta dalam menjalankan usaha. UMKM diminta untuk menetapkan target audience dari segmentasi yang sesuai dengan produk bisnisnya. Beragam faktor demografi kemudian digali dan diselaraskan dengan produk bisnis yang ditawarkan atau dijalani oleh UMKM.

\section{Evaluasi Hasil Kegiatan}

Dalam upaya mencapai target kegiatan secara optimal, maka dilakukan pula evaluasi hasil kegiatan. Evaluasi proses pelatihan dilakukan dengan tanya jawab dan pengamatan selama proses pelatihan diselenggarakan. Hal ini dilakukan untuk mengukur keberhasilan dan efektivitas Indikator keberhasilan selama proses pelatihan dilakukan, tim Lembaga Penelitian dan Pengembangan (LPPM) STIE Kesatuan melakukan penilaian terhadap keterlibatan dan kemampuan peserta pada setiap tahap pelatihan. Peserta cukup antusias dalam mengikuti acara tersebut, hal ini ditunjukkan dengan intensitas pertanyaan yang diajukan atas materi yang disampaikan.

Pertanyaan yang mendapatkan antusiasme tinggi di antaranya adalah bagaimana caranya untuk dapat memasang iklan di media sosial, seperti Facebook, Instagram, Youtube dan Twitter. UMKM juga kerap bertanya apakah hasil dari beriklan di media sosial akan sesuai dengan harapan dan bagaimana caranya memastikan iklan yang dipasang benar-benar membidik target sasaran.

\section{Pembahasan}

Kegiatan program Pengabdian kepada Masyarakat yang diselenggarakan oleh Lembaga Penelitian dan Pengabdian pada Masyarakat (LPPM) STIE Kesatuan, melalui pelatihan STRATEGI PROMOSI BERBASIS DIGITAL BAGI UMKM DI WILAYAH KOTA BOGOR, telah terselenggara dengan baik dan lancar. Secara umum pelaku UMKM memberikan respon positif atas pelaksanaan kegiatan ini, tertarik untuk dapat menerapkan materi pelatihan yang diberikan. UMKM tertarik untuk mencoba merancang program promosi yang tepat dengan memanfaatkan media sosial secara strategis. UMKM menyadari bahwa tanpa adaptasi bisnis yang baik, maka berpotensi menimbulkan kerugian dan kegagalan dalam optimalisasi bisnis. Dunia terus berubah, apabila tidak adaptif terhadap perubahan, maka tingga menunggu waktu untuk tergilas perubahan.

UMKM Kota Bogor yang menjadi peserta pelatihan mengharapkan kegiatan ini dapat diselenggarakan secara rutin dan berkesinambungan dengan topik yang lebih beragam sehingga dapat memberikan pemahaman mengenai bisnis yang sedang dijalankan yang dampaknya akan meningkatkan kinerja bisnis UMKM, khususnya di wilayah Kota Bogor. Dengan demikian pelaku UMKM dapat bersaing secara baik dalam kompetisi bisnis yang sedang berjalan ini.

\section{PENUTUP}

\section{Kesimpulan}

Pelaksanaan kegiatan Pengabdian kepada Masyarakat berupa pelatihan, STRATEGI PROMOSI BERBASIS DIGITAL BAGI UMKM DI WILAYAH KOTA BOGOR, berlokasi di Hotel Grand Asana Pangrango Bogor, telah dilaksanakan dengan baik. Indikator kepuasan dan antusiasme peserta, yakni UMKM di Kota Bogor atas pelatihan tersebut antara lain adalah sebagaimana disebutkan berikut ini.

1. Tercipta antusiasme yang tinggi dari peserta, menyimak setiap materi presentasi yang diberikan dan memberikan pertanyaan yang relevan, sesuai dengan kondisi yang dihadapi. Terjalin komunikasi dua arah antara narasumber dengan UMKM peserta
Pendampingan

Promosi Produk

UMKM

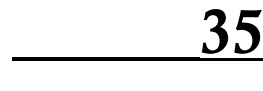

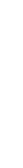


Pendampingn

Promosi Produk

$U M K M$

$\underline{36}$

\section{JADKES}

Jurnal Abdimas Dedikasi Kesatuan

Vol. 1 No. 1, 2020 pp. 29-36

IBI KESATUAN

E-ISSN XXXX - XXXX DOI: pelatihan.

2. Terjalin diskusi interaktif yang harmonis, peserta mau mencoba untuk merancang strategi promosi di media sosial dengan konten yang tepat. UMKM tertarik dengan cara merancang promosi periklanan melalui media sosial. Menetapkan target sasaran, merancang konten sesuai dengan anggaran periklanan yang tersedia dan melakukan engagement dengan target pasar sasaran.

3. UMKM peserta pelatihan, akan menindaklanjuti hasil pelatihan dengan mempraktekkan secara langsung sesuai dengan produk bisnis yang ditawarkannya.

\section{Rekomendasi}

Saran konstruktif yang dapat diberikan sehubungan dengan penyelenggaraan kegiatan pelatihan STRATEGI PROMOSI BERBASIS DIGITAL BAGI UMKM DI WILAYAH KOTA BOGOR, adalah sebagaimana disampaikan pada beberapa butir berikut:

1. Pelaku UMKM di wilayah Kota Bogor yang mengikuti pelatihan ini diharapkan dapat meningkatkan pengetahuan serta pemahamannya mengenai promosi di media sosial, untuk meningkatkan dan memperluas pangsa pasarnya. Selain itu diharapkan UMKM dapat mengoptimalkan promosi secara daring maupun luring, terintegratif dan tepat sasaran.

2. UMKM harus mampu memanfaatkan media sosial dalam menangkap peluang bisnis yang ada. Dengan demikian keberadaan media sosial dapat menjadi pintu masuk bagi datangnya pelanggan yang akan membeli produk bisnis yang ditawarkan

3. Pelatihan yang diselenggarakan bagi UMKM ini sebaiknya dilaksanakan secara rutin dan berkelanjutan. Dengan demikian dapat dievaluasi apakah pelatihan sebelumnya telah berdampak positif atau belum.

4. UMKM di Kota Bogor harus mampu merancang promosi periklanan dengan membuat konten-konten digital yang menarik dan sesuai dengan masing- masing karakteristik media sosial yang ada

\section{DAFTAR PUSTAKA}

Amaefule, Leonard I., Onyekpere, Ulumma R., and Kalu, Edith O. 2018. International Financial Reporting Standards and Manufacturing Firms' Financial Performance in Nigeria: A Study of Selected Quoted Firms. International Journal of Accounting and Taxation. Vol.6(1):103-114

Ariawati, 2005, Usaha Kecil dan Peluang Kerja, http://jurnal.unikom.ac.id/vol4/art7.html, diakses tanggal 3 maret 2005.

Hidayat, A. R., \& Kumadji, S. (2016). ANALISIS FAKTOR-FAKTOR YANG MEMPENGARUHI SIKAP KONSUMEN TERHADAP MOBILE ADVERTISING (Survei pada Mahasiswa S1 Fakultas Ilmu Administrasi Angkatan 2012/2013 Universitas Brawijaya yang Menggunakan Aplikasi Media Sosial LINE). Jurnal Administrasi Bisnis, 35(1), 137-145.

Purba, J.H.V., Ratodi, M., Mulyana, M., Wahyoedi, S., Andriana, R., Shankar, K. and Nguyen, P.T., 2019. Prediction Model in Medical Science and Health Care. International Journal of Engineering and Advanced Technology, 8, pp.815-818.

Sulistiono, S., Fadillah, A. and Putrie, D.E., 2020, May. Factors Affecting Bogor Botanical Garden Visitors' Intention Before and After the One Way System Application. In 2nd International Seminar on Business, Economics, Social Science and Technology (ISBEST 2019) (pp. 291-296). Atlantis Press.

Tan, A. M., Lestari, M. T., \& Ali, D. S. F. (2016). Respon Konsumen Pada Strategi Komunikasi Pemasaran Digital Dinas Pariwisata Ekonomi Kreatif, Pemuda Dan Olahraga Di Kawasan Wisata Mandeh Kabupaten Pesisir Selatan. eProceedings of Management, 3(2).

Undang-undang Republik Indonesia No.20 tahun 2008 Tentang Usaha Mikro, Kecil, Dan Menengah 